\title{
The System of Sandwich Courses in Higher Education at the Heart of Structuring a Small Island Territory: Lessons Learned from the Pioneering Example of The CFA University in the Corsican Region
}

\author{
Christophe Storaï ${ }^{1}$ and Laetitia Rinieri ${ }^{2}$ \\ ${ }^{1}$ University Institute of Technology Corsica- University of Corsica, Corte, France \\ ${ }^{2}$ Corsica-region University-sponsored Placements \& Apprenticeships Service [CFA UNIV], Campus \\ Grimaldi, Corte, France
}

Correespendece should be addressed to : Christophe STORAl; storai_c@univ-corse.fr

Received date: 29 March 2018; Accepted date: 11 June 2018; Published date: 3 November 2018

Copyright @ 2018. Christophe Storaï and Laetitia Rinieri. Distributed under Creative Commons CC-BY 4.0

\begin{abstract}
The specificity of the island economy of Corsica is characterized by the ascendancy of very small farmers and producers, of tradespeople which compose $95 \%$ of its entrepreneurial fabric. The fact remains that in the era of the globalization, this territory mediterranean islander of reduced size is completely involved in a problem of attractiveness in search of foundation to perpetuate its dynamics of growth.In this context, the politics of promotion and welcome of the investments geographically mobile presents a multidimensional character in which the socioeconomic environment and the existence of qualified human resources constitute fundamental parameters. For that purpose, the existence of a plan of human capital investment can establish an unprecedented opportunity to engage a virtuous trajectory of territorial development.It's precise in this perpective that the University vocational training center (CFA UNIV) in the Corsican region wishes, since its creation in January, 2009, to highlight the occupational integration of the students-alternants of the University of Corsica, as assets of valuation of the characteristic cardinal parameters of a territory in phase of structuring (simultaneous growth of the capacity of employability and the quality of the occupational integration of its human resources, massive evolution of the degree of skills' acquisition in direct links with needs emanating from the territory on the subject, fluidity of the transfert of the knowledge mastering thanks to the sandwich course training, sustainable raising awareness to the entrepreneurship...).After highlighting the specific features of University of Corsica's sandwich training programme as pivotal to Corsica island's Regional Vocational Development Programme Roadmap ['CPRDF'] strategy, this paper brings an analysis of the lessons learned from the pioneering example of the CFA UNIV in the Corsican region in the perspective of a dynamic conception of the Corsican territory's pattern of structuring and attractiveness.
\end{abstract}

Keywords: higher education - sandwich training - school-to-work transition - regional training policy structuring the socio-economic fabric of Corsica

Cite this Article as: Christophe Storaï and Laetitia Rinieri (2018)," The System of Sandwich Courses in Higher Education at the Heart of Structuring a Small Island Territory: Lessons Learned from the Pioneering Example of The CFA University in the Corsican Region ", IBIMA Business Review, Vol. 2018 (2018), Article ID 482281, DOI: $10.5171 / 2018.482281$ 


\section{Introduction}

The field of higher education and research has undergone major changes in recent years. Indeed, the French 'LRU' University Autonomy and Accountabilities reform of 10 August 2007 makes vocational readiness and school-to-work transition of core public service policy missions for higher education. Under LRU law, all higher education institutions are required to publish a number of statistics, including indicators on career placement rates.

In tandem, the University of Corsica-a major component in the island-region's higher education and research ecosystemsecured a new status as autonomous independent university in January 2009.

This new status brought a broader scope of missions, with the traditional missions tied to educating, training and transferring knowledge and competencies extended to also encompass registering and onboarding new students and coaching them on their personal and professional career plan through to successful completion; i.e. gaining the degree/vocational certificate and making the school-to-work transition.

That said, through legislation passed 13 May 1991 and bolstered by the later decentralization law of 22 January 2002, the CTC [Corsica-region local government] enjoys a wider set of prerogatives on higher education and research development policy than anywhere else in France.

Given this new landscape, the CTC and the University of Corsica elected to revamp their partnership and develop vocational training in higher education, chiefly through continuing professional education and apprenticeship schemes. Moving towards this goal, the challenge to make higher education an economic sector in itself, turning its knowledge and know-how into an exportable asset is now championed as a major driver of regional development strategy for the island's economy by everyone involved.

The strategy frameworking Corsica island's 2016-2020 Regional Vocational Development Programme Roadmap ['CPRDF'] included championing a policy of investment in human capital as a key foundation of a compelling regional brand, capable of shaping and selling the most vital valued assets that typify a regional territory emerging into a structured destination-brand identity (simultaneous growth in the employability and quality of school-to-work transition shown by its human capital, mass shift in the degree of skill acquisition directly tied to the regional territory's own organic needs, fluidity of knowledge transfer fully controlled through sandwich placements, deep sustainable entrepreneurship education, and so on).

This is where educational training strategies are a particularly key factor for spurring the availability of skilled qualified human resources and unlocking innovative highpotential entrepreneurship (Marchesnay et al, 2006). ${ }^{\mathrm{i}}$

After highlighting the specific features of University of Corsica's sandwich training programme as pivotal to Corsica island's CPRDF strategy, this paper brings an analysis of the lessons learned from the pioneering example of the CFA UNIV in the Corsican region with the prospect of a dynamic conception of a regional development's territorial scheme based on the economy of the knowledge. The findings of Ministrysponsored surveys on the transition-to-work track record of University of Corsica graduates since 2011 are analyzed to gain key learnings on job-to-training fit and structured entrepreneurial fabric in Corsica. 
The dynamics of University of Corsica's sandwich training programme as pivotal to Corsica island's CPRDF strategy

The law on vocational training, employment and social democracyii sets out the powers and authorities devolved to each agency and gives the region lead role in training and apprenticeship policy. Central government continues to hold authority over employment policy, while responsibility for youth and adult vocational training policy and strategy is devolved down to the regions. Employee training remains the remit of collective bargaining and labour relations. All these players are engaged in employment protection and career security measures, and all need to cooperate to organize lifelong learning and training opportunities.

This reform puts the final seal on the vocational training strand of the decentralization process, empowering the regions to deliver more cohesive action putting them at the forefront of vocational training policy. New powers and accountabilities have been devolved down to the regions, chief of which:

- training opportunities for special populations (prisoners, people with disabilities, expatriates);

- training services to help jobseekers get into work;

- funding working tax credit for all unpaid jobseekers and interns in vocational training; support and guidance to candidates for Accreditation of Prior Experiential Learning (APEL);

- designing and coordinating apprenticeship training agreements;

- a voice in how money raised by the apprenticeships levy gets spent.

The region has now become the most relevant geographic and legislative space for building training path policy- and in
Corsica, the CTC emerges as sponsor of a coherent and cohesive region-wide.

Objectives of the CTC-led CPRDF for the Corsican region

In a good governance effort designed to organizationally frame its powers under the specific prerogatives grantediii, the Collectivité Territoriale de Corse-Corsicaregion's local government council, in line with the island's Regional Vocational Development Programme Roadmap ['CPRDF'], gave itself six objectives:

1. Fill gaps in the island-wide economic fabric and secure paths to employment:

- by identifying the organic needs of the region's economy;

- by joined-up governance for stable sustainable areal development;

- by empowering all populations with opportunities to get training and basic vocational qualifications.

2. Serve, inform, guide and support all populations on a fair and equal basis across the territory.

3. Lend impetus to sandwich training:

- by strengthening ties between sponsor businesses, placement structures and training centres;

- by promoting and expanding sandwich training solutions;

- by working to pre-empt early termination of training agreements;

- by scouting for new opportunities to leverage sandwich training prospects.

4. Weave best quality practice into in the training system: 
- by giving training-offer professionals the training and tools they need for their service, information, guidance and support roles;

- by engineering and optimizing the training infrastructure to deliver a local community-tailored training offer reaching out across the island and into the rural areas.

5. Progressively integrate Corsican language and culture across every echelon of vocational training and apprenticeship across the region, spearheaded by developing a Corsican-language certification scheme in every sector of training.

6. Facilitate employability and empowerment initiatives to get school-leavers and workingage people into work as part of a balanced and inclusive areal development policy.

These same objectives are also listed as strategic foundations written into the University of Corsica's 2018-2022 -year objectives roadmap.

The University of Corsica sandwichplacement system tailored to a smallisland economy

It is precise for this University of Corsica sandwich-student school-to-work transition issue, reframed as pivotal to local regional development strategy, that the CFA UNIV aims to highlight a real-world example of how to deal with specific constraints facing a small-island economy.

The specificity of the island economy of Corsica is characterized by the ascendancy of very small farmers producers and of tradespeople which compose $95 \%$ of its entrepreneurial fabric.

Corsica also offers a case-in-point example of an areal region characterized by an ageing labour force making it necessary to realign mid-term regional vocational training strategy in response to this inescapable reality. As a major lever of local-regional development and social regulation policy, the island's vocational training system has to readapt its offer to achieve the targeted job-totraining fit. Continuous professional education and the sandwich-course system (apprenticeships, sandwich-course internships) are, therefore, the two core strands of the same policy platform designed to structure and build the competency levels, qualifications and employability of the employed and unemployed labour force across a given territory.

In this setting, the CFA UNIV is tasked with handling the promotion, development, and administrative-educative-financial

management of the sandwich-course system at the University of Corsica. Aligning its operational imperatives to the island's community fabric, it fosters initiatives designed to co-accommodate target populations (pure-graduate students, sandwich-placement students, employees). This cross-fertilization framework makes it possible to capitalize on innovative instructional practices while harnessing and networking the actors and agents involved (University of Corsica, CTC, businesses, community groups, local authorities, OPCA [government agencies handling subsidized professional training], jobsearch agencies, the big chamber organizations) who are engaged in school-to-work training and transition.

With commentators touting the knowledge economy as the only way out from endemic economic crisis, the CFA-UNIV has taken a pro-active role by engaging in a process to structure a consolidated, sustainable socioeconomic fabric through optimized management of a vocational training/information, guidance services and tailored careers support system for University of Corsica graduates.

The Ministry-sponsored surveys' conception on the transition-to-work of University of Corsica sandwich-placement students ${ }^{\text {iv }}$ 
For this purpose, a specific survey methodology designed to capture the schoolto-work transition track record of University of Corsica sandwich placement students were adopted as a performance instrument but also to provide statistical support to predictive policy building on directions that future vocational training efforts should take in order to fill human resources gaps in the Corsican socio-economic fabric. This predictive strand is a crucial factor, as the analyses produced are designed to guide the political (CTC) and institutional (the University) decision-makers in their coordinated effort to roadmap a vocational strand of Corsica-region higher education geared to local-specific factors and variables.

The CFA UNIV has, thus, conducted six annual surveys on the of the transition-towork track record of University of Corsica students/graduates. ${ }^{v}$

\section{Specifically-tailored methodology}

The specific survey methodology employed to capture the school-to-work transition track record of the sandwich-placement students (questionnaire send-out followed by telephone and email chase-up) afforded a mean response rate of $87,6 \%$ (soit 862 répondants sur 983 interrogés pour les six enquêtes i.e. 862 respondents out of 983 people surveyed over the four surveys) ${ }^{\mathrm{vi}}$, which is a statistically representative panel of the total population. The analyses developed are built around nine core focuses:

\footnotetext{
$>$ Professional status of the student

$>$ Job level (occupational category)

$>$ Time gap before integrating the current position

$>$ Contract type (long-term, shortterm,...)

$>$ In-job salary of the student

$>$ Job-to-training fit (whether the job position is an extension of curriculum completed)

$>$ Geographic location of the job found

$>$ Structure taking on the sandwichcourse leaver (businesses, community groups, local authorities)
}

$>$ Link to the initial sandwichplacement structure (are sandwichplacement students employed under the same roof?

\section{A diversity of characteristic University of Corsica vocational curriculum courses}

The University of Corsica vocational curriculum courses surveyed illustrate five core activity areas which represent opened up university teaching to directly fill gaps in the island-wide socio-economic fabric.

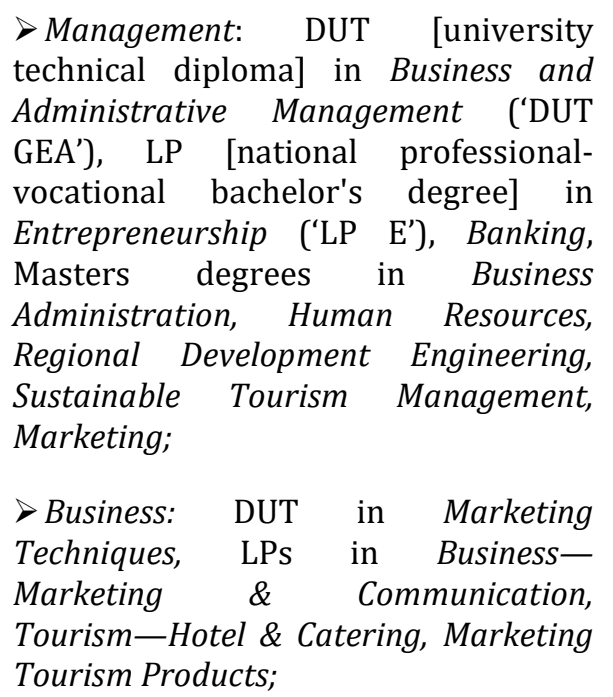

$>$ Computing and Communications: DUT in Multimedia and Internet Technology, LP in Communication techniques and Channels, DU [university-issue degree diploma] in Audiovisual Engineering, Masters degrees in Internet \& Information Systems, Landscapes, Heritage \& Media in Europe and the Mediterranean, Cultural Product Engineering;

> Industry: DUT in Civil Engineering, Biological Engineering (biotech \& foodfarming industries), DEUST [university science and technology diploma] in Environmental Biology Analysis, LPs in, Civil Engineering and Construction Work, Electricity, Electronics and Industrial Systems, Masters degree in 
Mediterranean Food-Farming Systems Engineering;

D Environmental Science: DUT in Biological Engineering (environmental engineering), HealthSafety-Environment, LP Water and Environmental Governance, HealthSafety-Environment-Quality, Energy \& Climate Engineering - renewable resource management, Masters degrees in Energetics \& Renewable Energies, Water and Environmental Science, Integrative Management of Coastline, Ecosystems and Major Hazard Control, Ecological Engineering.

In total, 34 applied vocational courses were targeted, counting 903 students including 307 sandwich-placement students vii.

Moving from expected outcomes to predictive values ready to devise a regional development policy based on the knowledge economy

Stemming from the University of Corsica's ministerial accountabilities (nationally- coordinated regional-scale survey led by universities offering a broad-spectrum vocational development curriculum), the CTC, simultaneously exercising its mission to promote regional apprenticeship schemes and its mission to validate the map of regional-scale coverage of training programmesviii, commissions the CFA UNIVto annually provide tangible figures on graduation rates and school-to-work transition record to inform and shape political policy decisions on the island's 'CPRDF' roadmap.

This tool, wielded by regional government, informs mid-term regional vocational training policy and the aligned coordination of the vocational training paths on offer. To forge this regional plan, the CTC relies on active input from Corsica's educative, economic and social community networks.

\section{Report and analysis of the main findings}

The raw data and the findings reported here are taken from the four apprenticeship-towork surveys conducted by the CFA UNIVix.

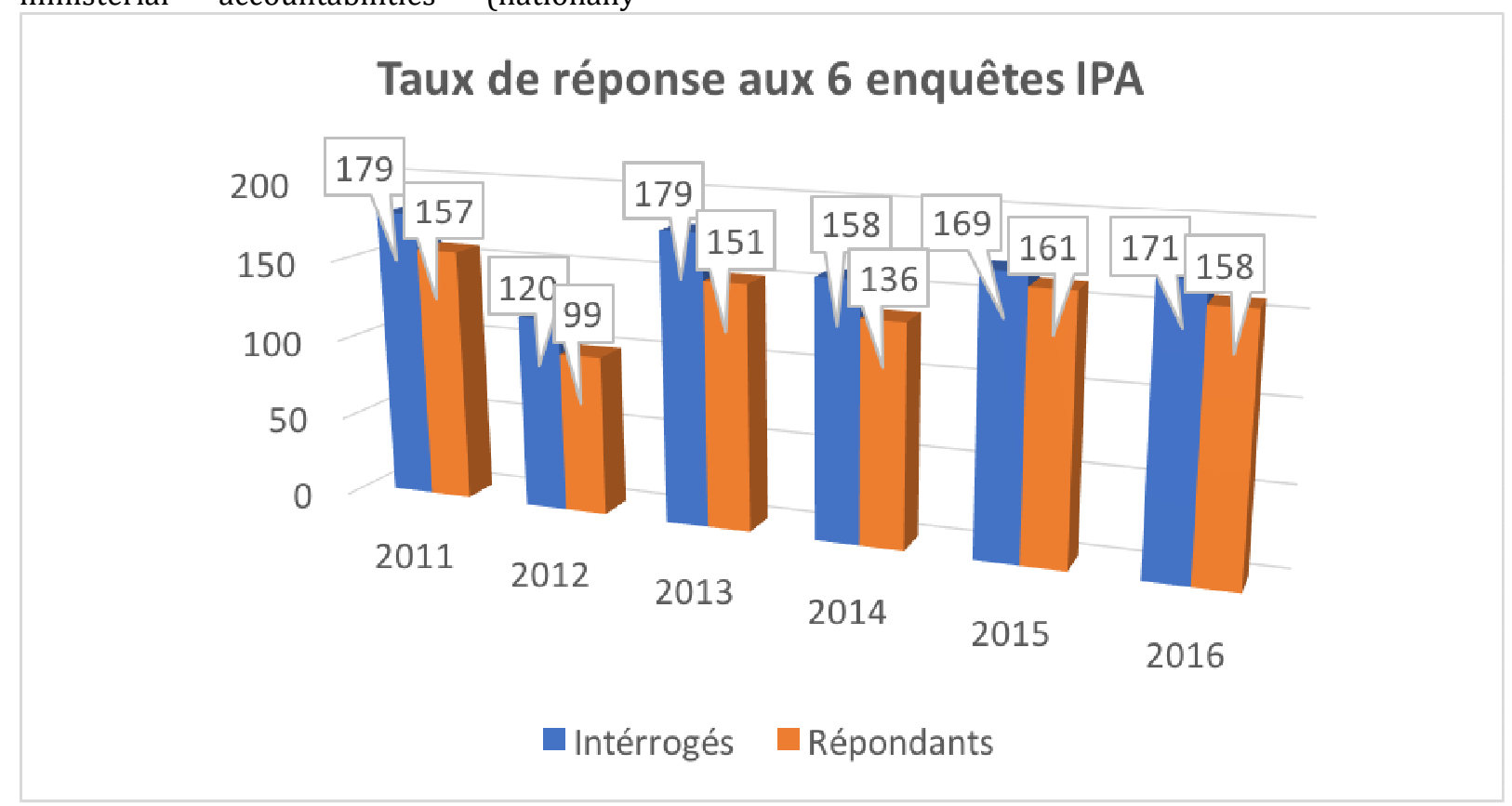

Figure 1 : Response rates to the 6 apprenticeship-to-work surveys 
a) Breakdown distribution of sandwich-placement students in the 5 core activity areas which represent opened up university teaching to directly fill gaps in the island-wide socio-economic fabric

\section{Répartition des étudiants- alternants par domaine d'activité lié à la formation}

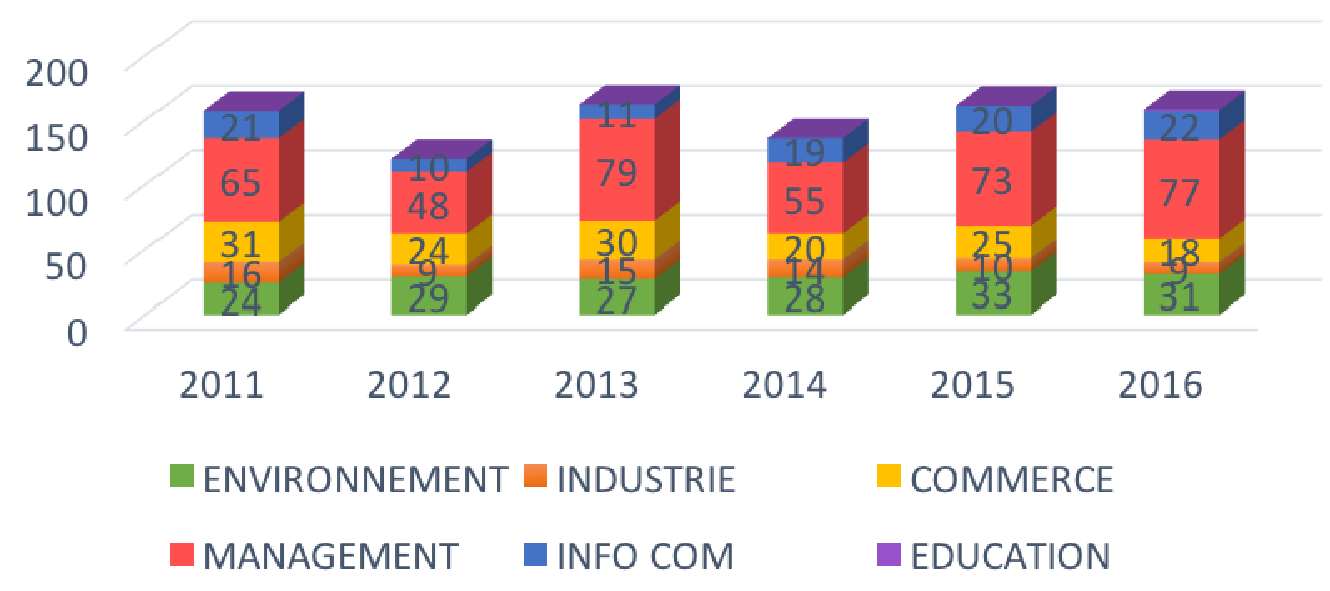

Figure 2: Distribution of sandwich-placement students broken down by vocation training discipline 
b) Distribution of sandwich-placement students broken down by diploma

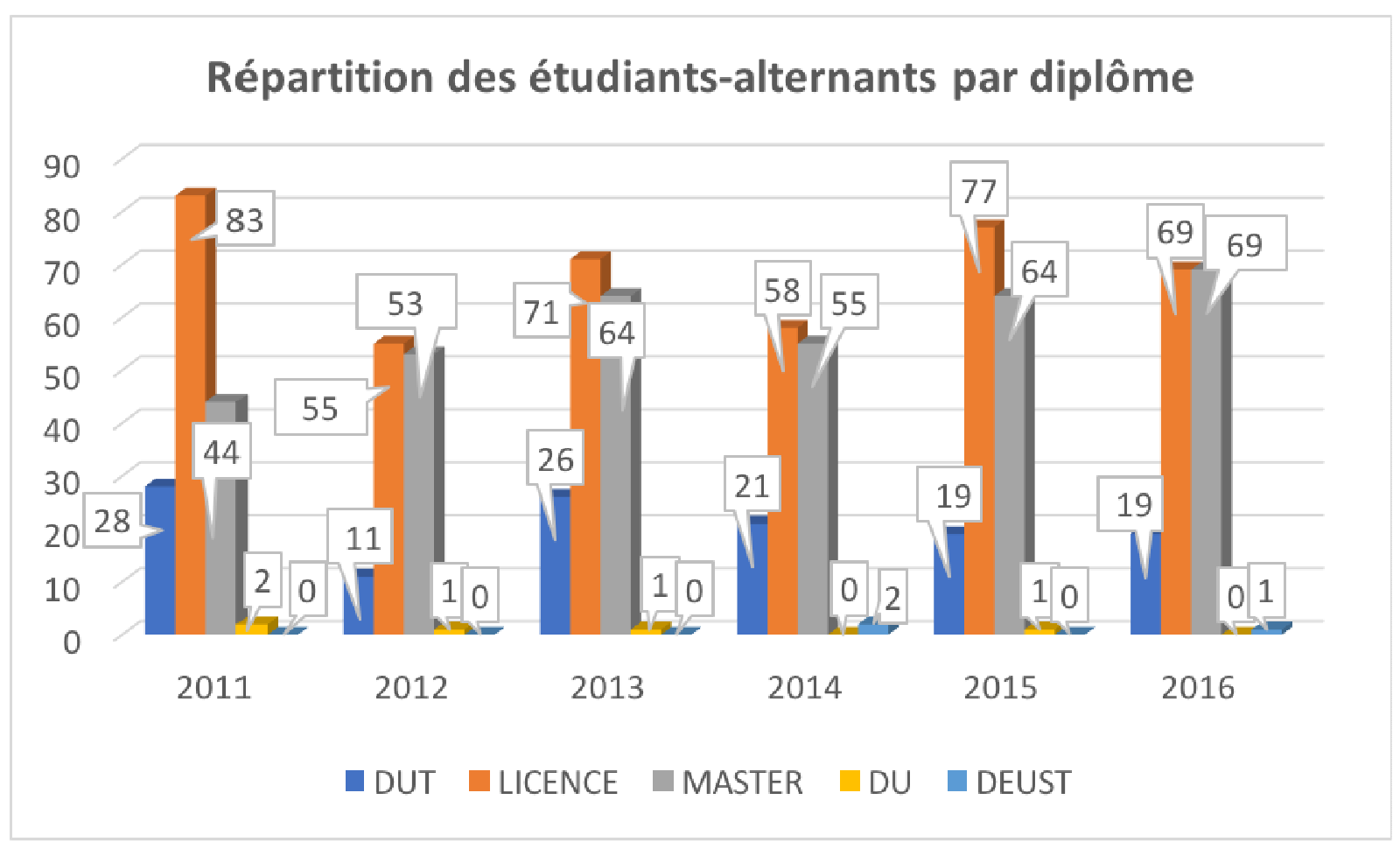

Figure 3: Distribution of sandwich-placement students broken down by diploma 
c) Career situation of sandwich-course leavers

\section{Situation des étudiants-alternants sortants}

150

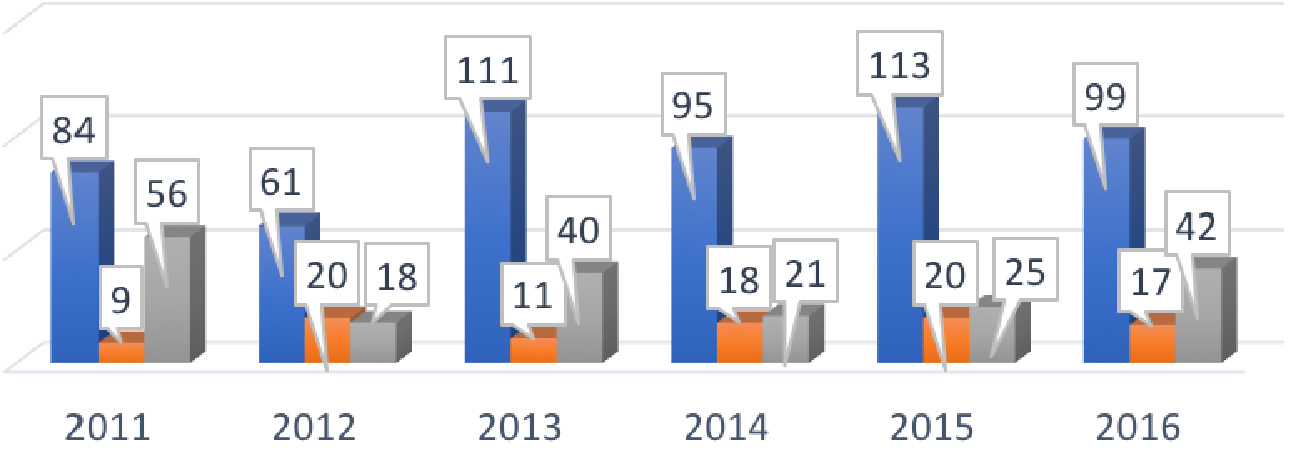

0

2011

2012

2013

2014

2015

2016

EMPLOI SANS EMPLOI ETUDIANT

Figure 4: Career situation of sandwich-course leavers

d) Types of job contracts held by sandwich-course leavers

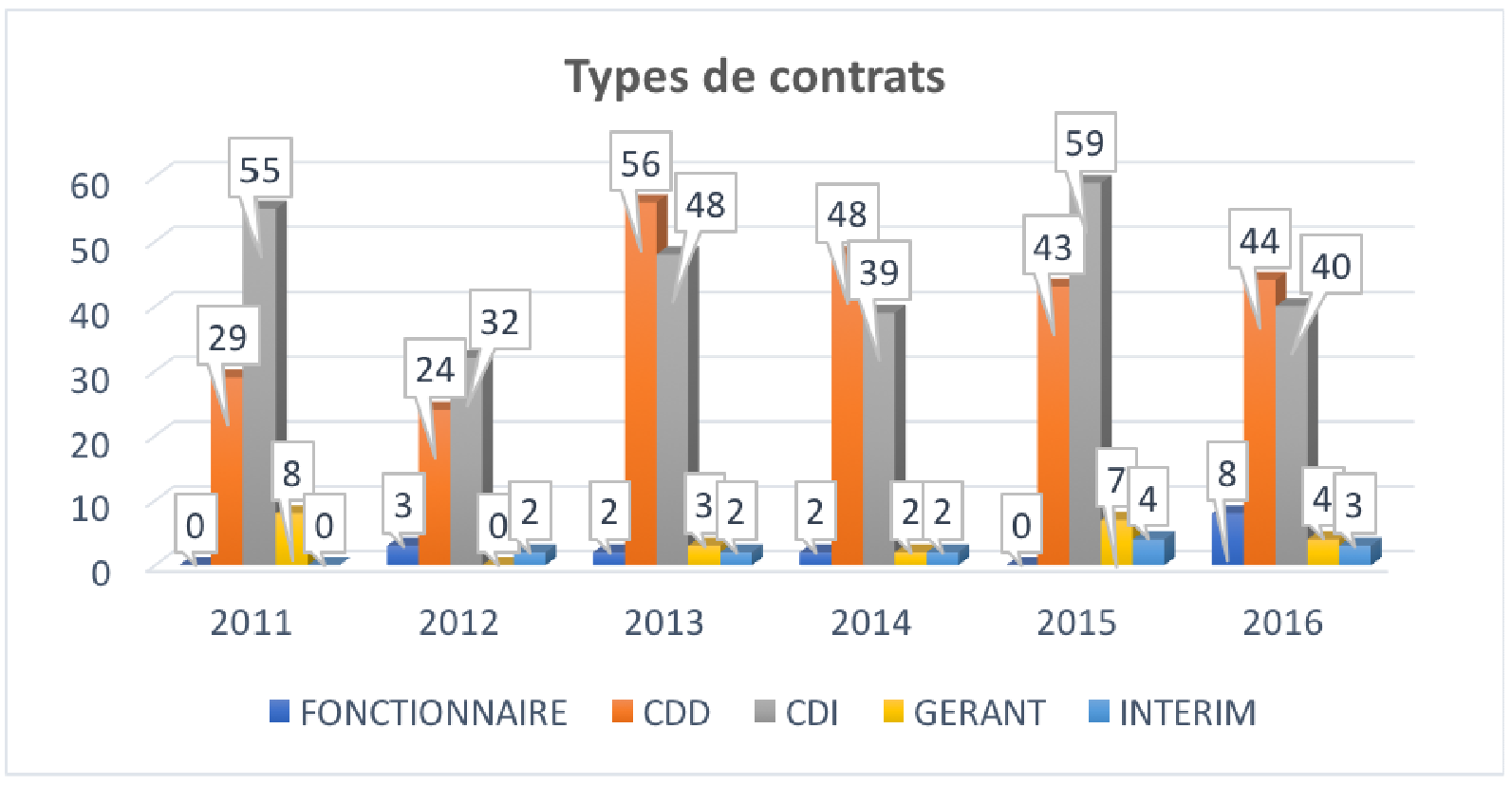

Figure 5: Types of job contracts 
e) Type of occupationnal categories held by sandwich-course leavers

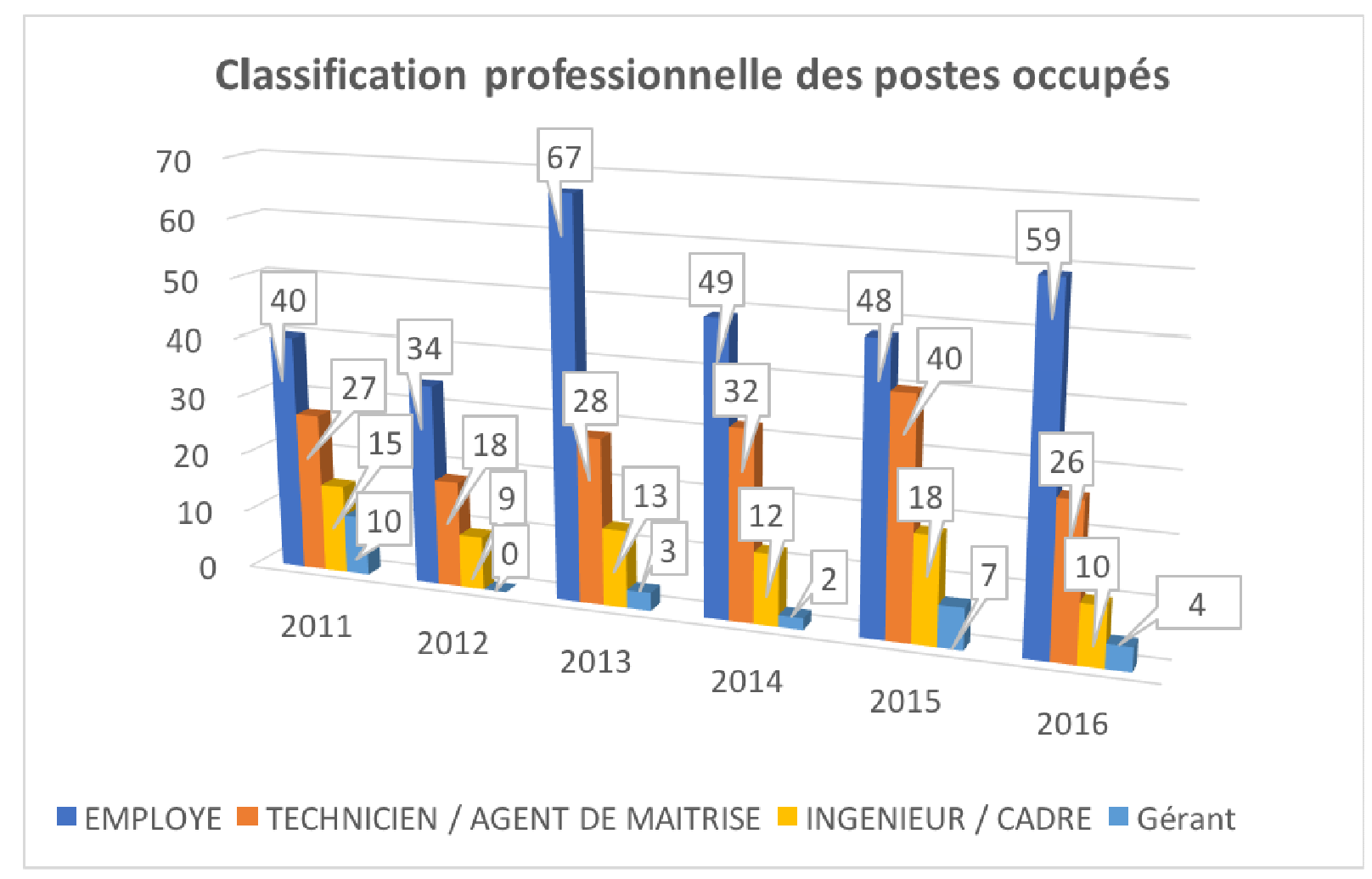

Figure 6 : Professional classification of the jobs held 


\section{f) Lob-to-training fit for sandwich-course leavers}

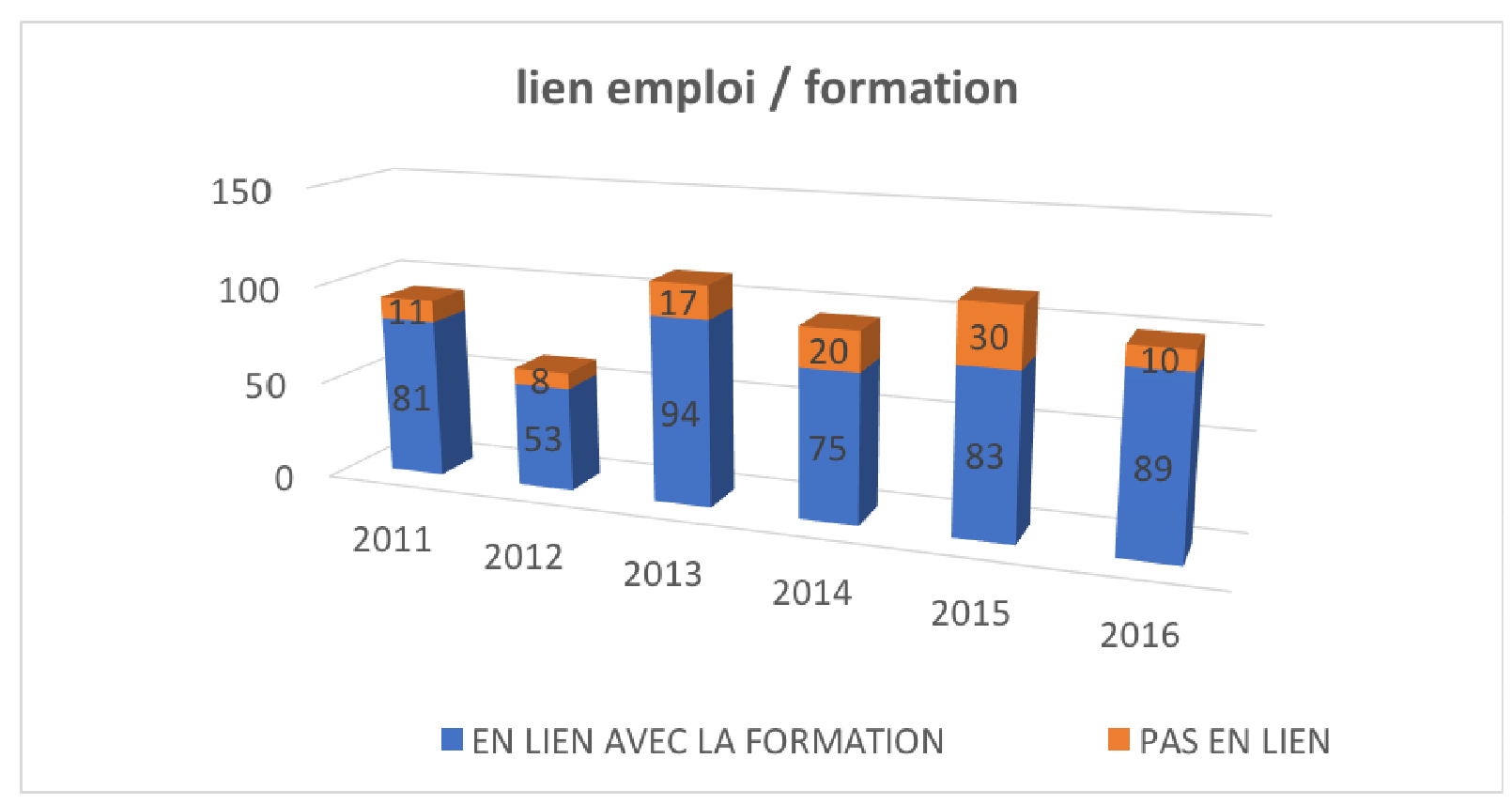

Figure 7 : Job-to-training fit 
g) Type of structures taking on sandwich-course leaversx

\section{Types de structures d'accueil des étudiants-alternants} sortants

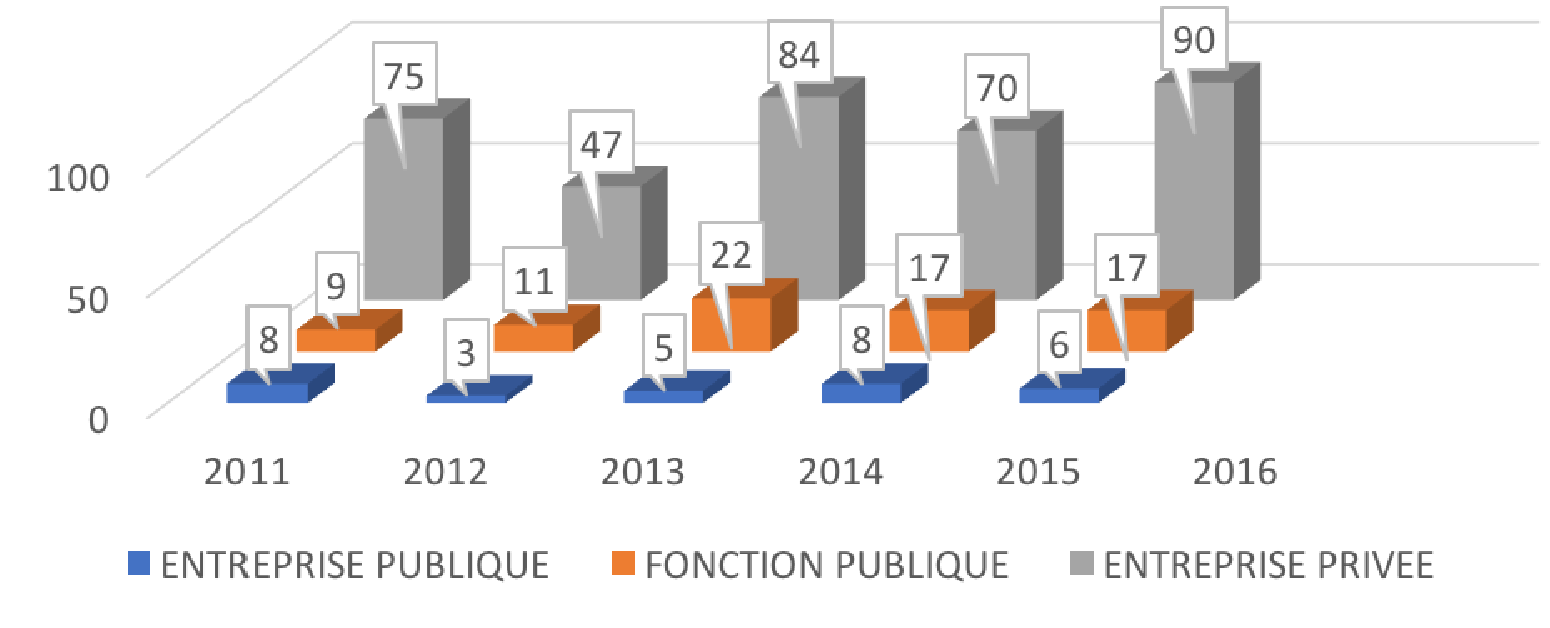

Figure 8 : Type of structures taking on sandwich-course leavers 
h) Size of structures taking on sandwich-course leavers ${ }^{x i}$

\section{Taille des structures d'accueil}

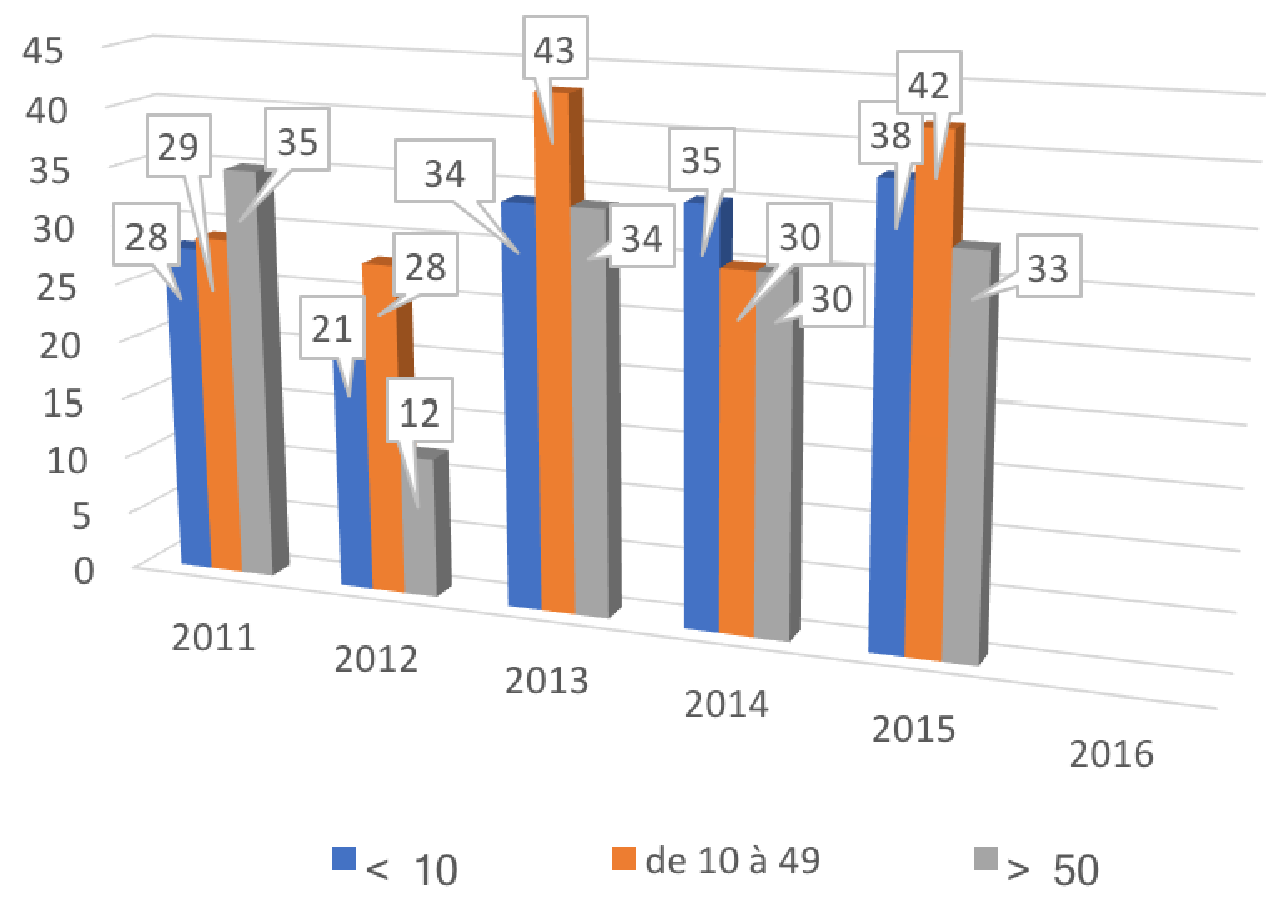

Figure 9 : Size of structures taking on sandwich-course leavers 
i) Geographic location of jobs found by sandwich-course leavers

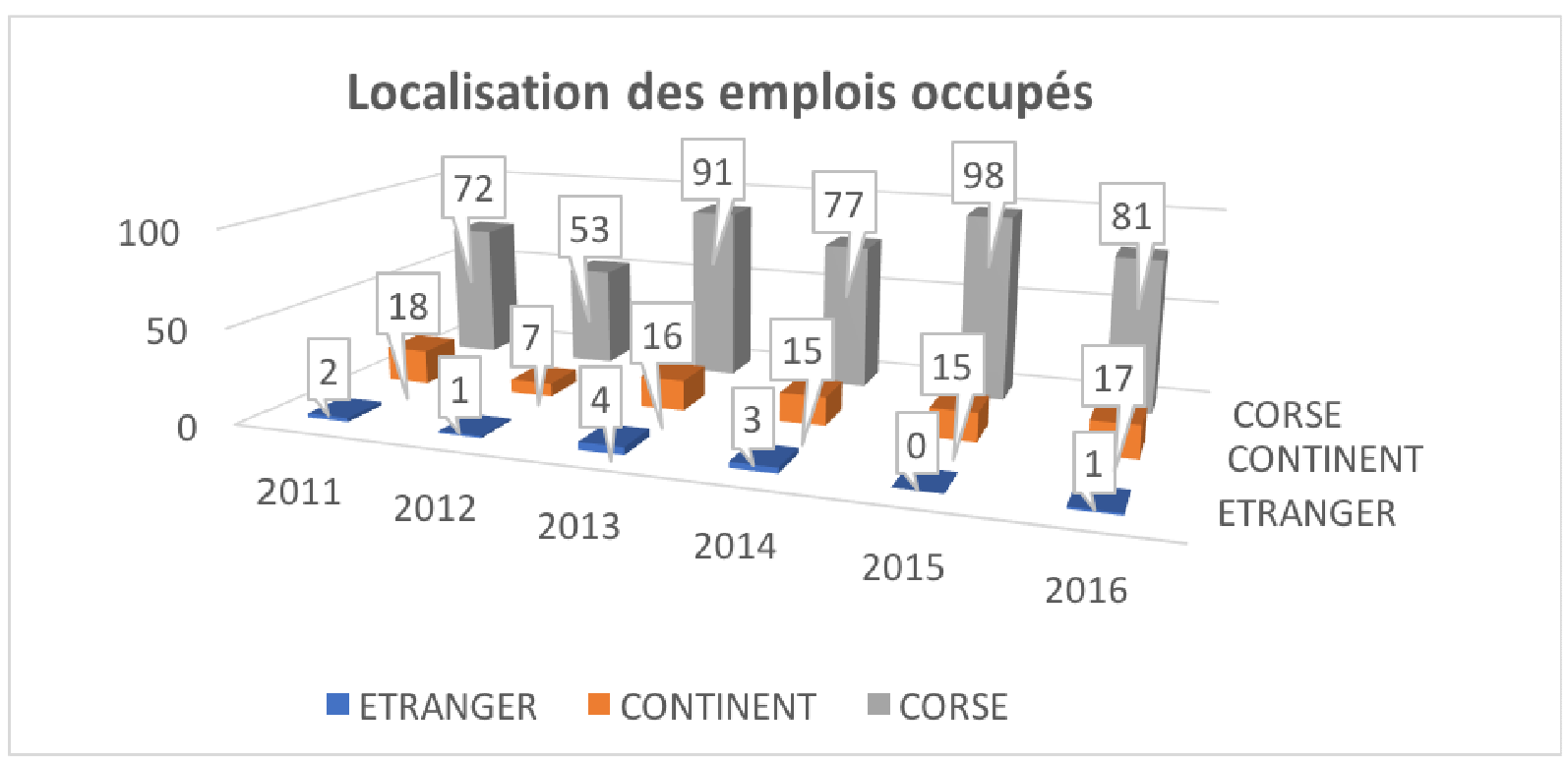

Figure 10 : Location of job contracts held 
j) Salary brackets of job contracts held by sanswich-course leavers ${ }^{x i i}$

\section{Salaire des emplois occupés}

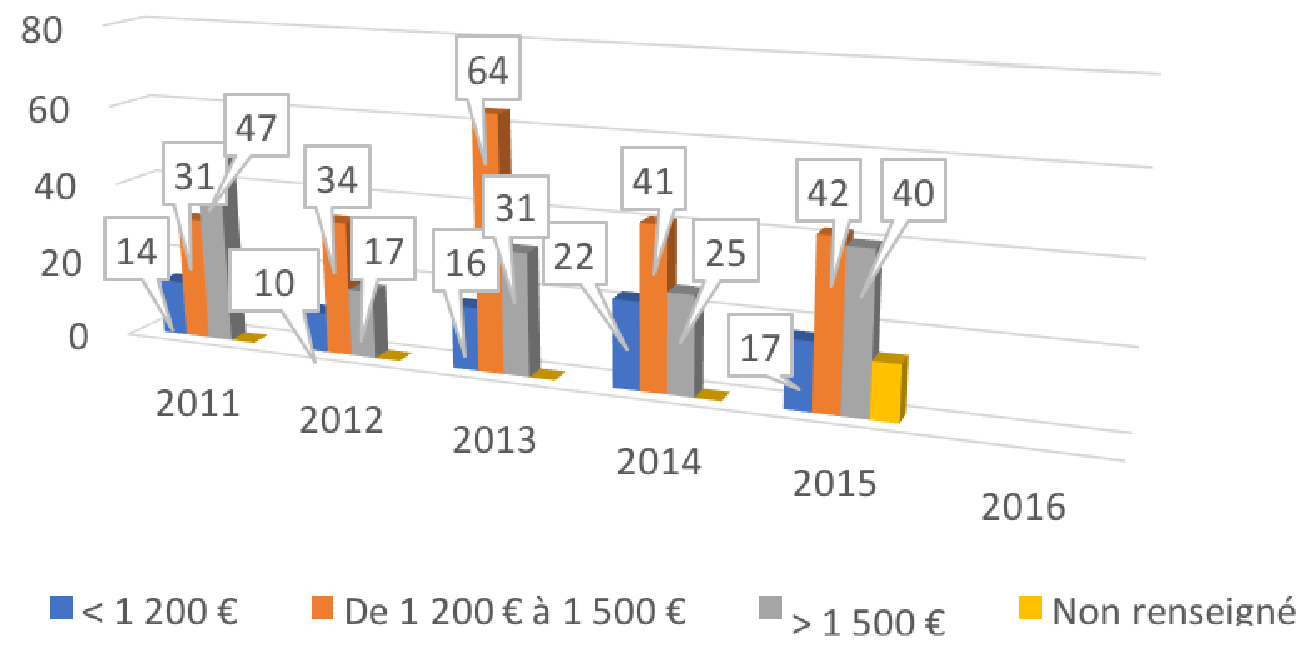

Figure 11 : salaires des emplois occupés

k) Examples of the kinds of jobs held by sandwich-course leavers

$>$ communication manager;

$>$ communication assistant

$>$ sales representative;

$>$ accountant;

$>$ research officer;

$>$ project site supervisor;

$>$ web designer;

$>$ laboratory technician;

$>$ construction superintendent;

$>$ network leakage technician;

$>$ PR assistant;

$>$ customer support assistant;

$>$ PR officer;

$>$ client services advisor;

$>$ quality control specialist;

$>$ risk prevention engineer... 
1) Situation of sandwich-course leavers continuing in education at another faculty

\section{Situation des étudiants-alternants sortants en poursuites d'études dans un autre établissement}

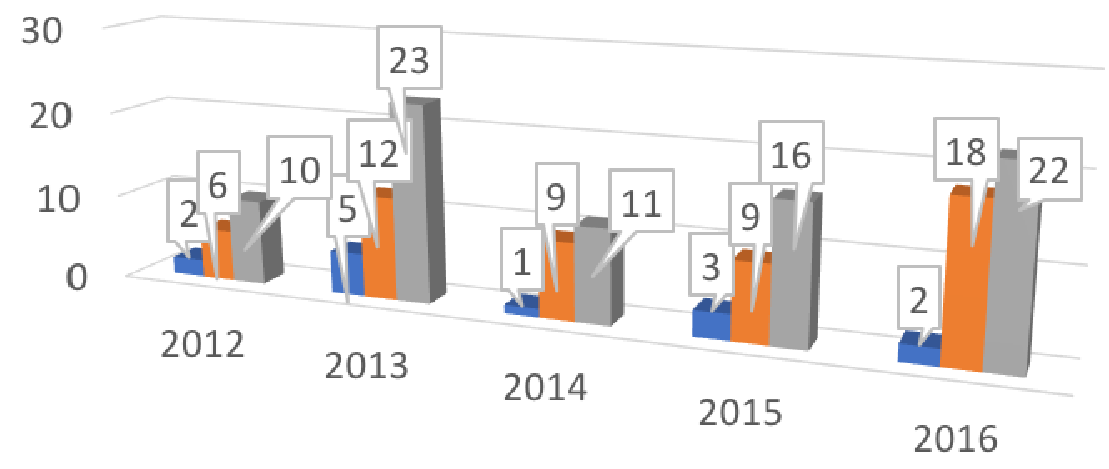

Stage de formation Apprenti Etudiant initial

Figure 12 : Situation of sandwich-course leavers continuing in education 
m) Reasons pushing sandwich-course leavers to continue education at another faculty

\section{Raisons des poursuites d'études dans un autre établissement}

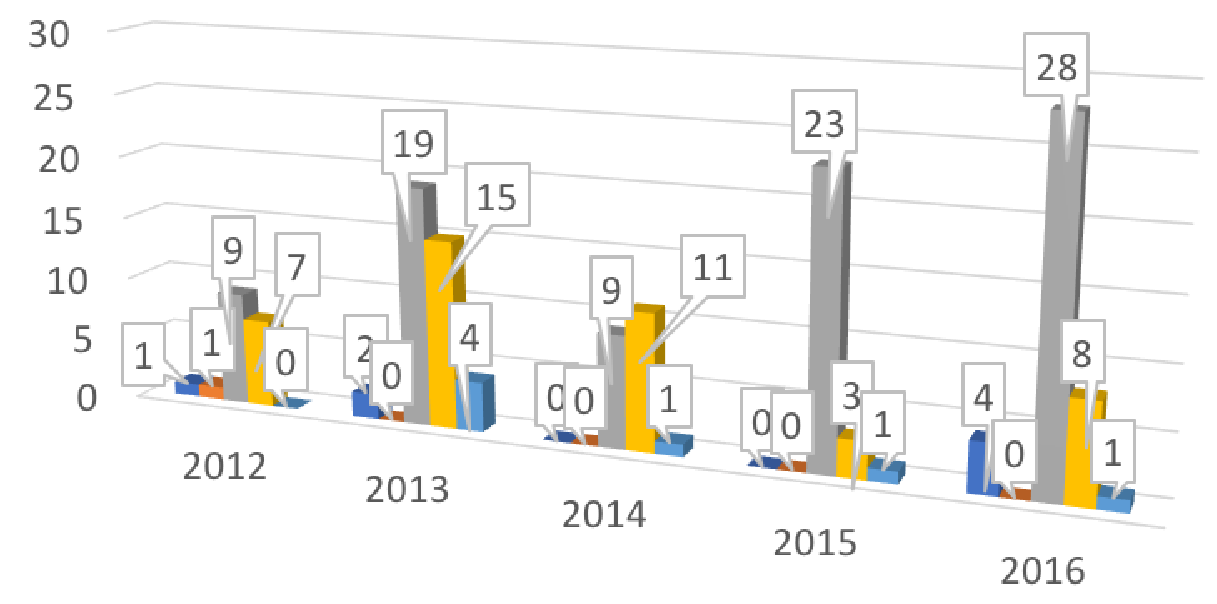

Examen non validé

Par choix
Réorientation

Besoin d'une nouvelle qualification

Parce que sans emploi

\section{Figure 13 : Reasons pushing sandwich-course leavers to continue in education at another faculty}

The findings of the four CFA-UNIV-led apprenticeship-to-work surveys provide the island's public policymakers with concrete figures and trendlines that can help shape a general roadmap for regional human capital development and a targeted regional policy strategy for vocational training in higher education.

A handful of key figures ${ }^{x i i}$ paint this picture clearly:

$67 \%$ of sandwich-course leavers are in employment at 6 months after the last vocational training course attended;

$>86 \%$ of job contracts held fit the vocational training course(s) attended, with $82 \%$ located in Corsica;

$>53 \%$ of job contracts held are sustainable employment prospects, of which $6 \%$ are tied to sustainable entrepreneurship projects;

$>35 \%$ of these positions correspond to a take-home monthly salary (before bonuses) of over $€ 1500$;

$>89 \%$ of decisions to continue in education were driven by personal reasons and a need for further 
qualifications, with only $7 \%$ prompted by failure to find a job;

$>69 \%$ of job contracts held are in microenterprises and small businesses, in line with the structured entrepreneurial fabric of Corsica's island economy.

The University of Corsica sandwichplacement system is not just a gateway into employment but also a pathway to excellence, as $75 \%$ of graduates completing the 34 all-population courses (pure-graduate students, sandwich-placement students,

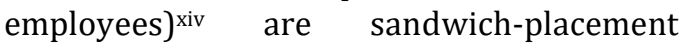
students.

\section{Conclusion}

The survey findings point to particularly encouraging signs on employability and quality of school-to-work transition of University of Corsica students, especially in the analysis of targeted job-to-training fit. This grass-roots reality opens up promising future perspectives for a structured entrepreneurial fabric in Corsica built on the sandwich-course system platform where placement businesses are centrally empowered to train up young local talent.

Ultimately, the overriding objective remains to successfully coordinate the impetus given to vocational training as a solution to fill gaps in the island-wide socio-economic fabric (maximization of the job-to-education fit) through the emergence of sandwich-course training channels (levels III, II and I) ${ }^{\mathrm{xv}}$. Moving towards this objective, the findings of the CFA UNIV apprenticeship-to-work surveys provide regional public policymakers with positive concrete guidance.

From this perspective, the expertise of CFA UNIV brings insights that are liable to guide strategic decisions on vocational training policy, employment policy, and how to structurally shape the island as a social and economic area. These findings will be presented as part of a wider initiative to build a regional development policy based on the economy of the knowledge decision support tool focused on the theme of areal planning and regional branding for Corsica.

\section{References}

1. Assemblée de Corse, (2016), «Le dispositif apprentissage 2016/2017» Rapport $n^{\circ} 2016 / E 5 /$ session extraordinaire 28-29 juillet.

2. Colletis G. et Pecqueur B., (1996), «Firmes et territoires : entre nomadisme et ancrage.», Revue Espaces et Sociétés $n^{\circ}$ spécial.

3. Dares résultats, (2017), L'apprentissage en 2016, 4 septembre.

4. Marchesnay M., Kammoun S.C. et KARRAY H.E., 2006, «Y-a-t-il un entrepreneuriat méditerranéen?» Revue Française de Gestion, Vol. 32. $n^{\circ} 166$.

5. Storaï C., Rinieri L. et Boulenger M., (2014), "Sandwich-Course Training in Higher Education as a major Strategic Thrust Regional Policy of Professional Training: Lessons Learned From the Pioneering Example of the University Institute of Technology Corsica», Chinese Business Review, Volume 13, Number 2, February (Serial Number 128) pp.101-110.

6. Storaï C. et Rinieri L., (2016), « Regional human capital development policy and Sandwich placement training in higher education: lessons learned from the pioneering example of the University of Corsica in a small island economy ", Chinese Business Review, ISSN 1537- 1514 May, Vol. 15, No. 5, 243-257.

7. Storaï C., Rinieri L. et Rezzi A., (2017), "L'alternance dans l'Enseignement Supérieur et la sensibilisation à l'entrepreneuriat : le cas des diplômés du CFA Universitaire en région Corse », 29th IBIMA Conference, Vienna, 3-4 May.

8. Veltz P., (1996), Mondialisation, villes et territoires. L'économie d'archipel, Paris PUF. 
i Extending on this idea, localized productive ecosystems - built on the competitiveness clusters model founded on core tech research, and engineered with SMEs well engaged in the governance framework - offer a potential source of sustainable regional-level structural planning and development (Veltz, 1997; Colletis \& Pecqueur, 1996).

ii Promulgated on March 6th, 2014

iii See French decentralization policy on Corsica passed into law on 22 January 2002:

http://www.legifrance.gouv.fr/affichTexte.do?cidTex te $=J O R F T E X T 000000409466 \&$ categorieLien $=i d$

iv The CFA UNIV conducts the annual apprenticeship-to-work transitions ('IPA') survey specific to University of Corsica sandwich-placement students (tracking transition to employment of all (graduate or non-graduate) sandwich-course leavers as of March the following year).

${ }^{\mathrm{V}}$ The CFA UNIV has led six apprenticeship-to-work surveys on the transition-to-work track record of sandwich-course leavers in 2011, 2012, 2013, 2014 2015 and 2016. The term leaver refers to where the student surveyed currently stands: he/she either (i) graduated from the last vocational training course they attended, left school and is currently in (or looking for) work, or (ii) failed to graduate or dropped out mid-year and does not envisage going back to school. The student is therefore currently in (or looking for) work.

vi Exact figures put the survey response rates from the sandwich-placement students concerned at $87.8 \%$ in 2011 (157 respondents out of 179 surveyed), $82.5 \%$ in 2012 (99 respondents out of 120 surveyed), $84.4 \%$ in 2013 (151 respondents out of 179 surveyed), $86.1 \%$ (136 respondents out of 158 surveyed) in $2014,95,2 \%$ (161 respondents out of 169 surveyed) in 2015 and $86.1 \%$ (158 respondents out of 171 surveyed) in 2016.

vii Six-year average.

viii See earlier under point iii.

ix See earlier under point $\mathrm{v}$

${ }^{\mathrm{x}}$ Unavailable data in 2016

${ }^{x i}$ Unavailable data in 2016

xii Unavailable data in 2016

xiii six-year average figures

${ }^{\text {xiv }}$ See earlier under point vii.

xv i.e. the National Classification of Levels of Training used, especially for statistical purposes, as a metric of educational attainment. Skill level III is for staff with a job normally requiring a DUT or a Brevet de Technicien Supérieur (BTS) or end of undergraduate higher education. Skill level II is for a person with a middle management job that normally requires Bachelor's degree or LP-level training. Skill level $I$ is for a person with a middle management job that normally requires a training above the first-year Master's degree level. 